ophiodiicola, the fungus associated with snake fungal disease. BMC Vet Res. 2015;11:95. https://doi.org/10.1186/ s12917-015-0407-8

8. Martel A, Blooi M, Adriaensen C, Van Rooij P, Beukema W, Fisher MC, et al. Wildlife disease. Recent introduction of a chytrid fungus endangers Western Palearctic salamanders. Science. 2014;346:630-1. https:// doi.org/10.1126/ science. 1258268

9. Burrowes PA, De la Riva I. Unraveling the historical prevalence of the invasive chytrid fungus in the Bolivian Andes: implications in recent amphibian declines. Biol Invasions. 2017;19:1781-94. https://doi.org/10.1007/ s10530-017-1390-8

10. Campana MG, Kurata NP, Foster JT, Helgen LE, Reeder DM, Fleischer RC, et al. White-Nose Syndrome Fungus in a 1918 bat specimen from France. Emerg Infect Dis. 2017;23:1611-2. https:/ / doi.org/10.3201/eid2309.170875

Address for correspondence: Jeffrey M. Lorch, US Geological Survey National Wildlife Health Center, 6006 Schroeder Rd, Madison, WI 53711, USA; email: jlorch@usgs.gov

\section{Buffalopox Disease in Livestock and Milkers, India}

\author{
Parimal Roy, Andrew Chandramohan \\ Author affiliation: Tamil Nadu Veterinary and Animal Sciences \\ University, Chennai, India
}

DOI: https://doi.org/10.3201/eid2707.202111

Buffalopox outbreaks caused by vaccinia virus were observed in villages of Tamil Nadu, India, among lactating buffaloes and cows. Milkers also had lesions on their fingers. Because vaccinia virus is known to have extended its host range in Brazil, we recommend continuous surveillance to understand cross-species transmission and to curtail disease effects.

$I^{1}$ n India, sporadic outbreaks of buffalopox, which can be caused by vaccinia virus (VACV), have been reported among cattle and buffaloes (1-3) and also in humans (3). We describe an outbreak affecting 120 lactating buffaloes and 40 lactating cows in Kannivadi, Navapatti, Alathuranpatti, Maniakaranpatti, Muthukumaranpatti, S.Pudur, and E.Chittor,
Dindigul district; and in Krishnarayapuram, Karur district, in Tamil Nadu, India in 2004. Pock lesions (0.5-1 cm diameter) were seen over the bodies of lactating buffaloes but restricted to only the udder and teats of lactating cows (Figure, panel A). Buffalopox did not cause death in the animals we reviewed; it affected more buffaloes $(30 \%-50 \%)$ than cows $(20 \%-$ $30 \%$ ). Suckling calves developed pock lesions on the forehead, lips, and mouth. Three milkers who worked with the affected animals experienced multiple pock lesions (1 cm diameter) on the fingers, interdigital webs, wrist and forearm (Figure, panel B) and generalized effects including fever $\left(100^{\circ} \mathrm{F}\right)$ and enlargement of axillary lymph nodes.

To investigate the causative agent, we used existing clinical samples. Scab samples were collected randomly from 20 affected animals (both buffaloes and cows). We examined scab suspensions under transmission electron microscope (EM) at $80 \mathrm{KV}$ and inoculated the suspension in BHK21 cell line for virus isolation. We examined scab homogenates and cell culture fluid by PCR for differential diagnosis of cowpox virus and VACV infection (4). EM revealed typical brick-shaped pox virus particles of $\approx 290 \times 270$ $\mathrm{nm}$ with irregularly arranged superficial filaments formed by tubules (Figure, panel C). After 2 blind passages, we noticed in BHK21 cell lines cytopathogenic effects such as cellular rounding, cellular fusion, and intracytoplasmic inclusion bodies (Figure, panel D) after 48-60 hours of infection; PCR analysis revealed the causative agent to be VACV.

During the global eradication of smallpox, strains of VACV were used as vaccine. VACV infection sometimes transmitted from the vasicular lesion of vaccinae to domestic animals, usually cattle; in turn, infected animals transmitted VACV to susceptible humans (5). Several outbreaks in cattle and humans that were thought to be cowpox were in fact caused by VACV $(1,6,7)$. The infected animals were treated with parenteral injection of antimicrobial drugs for 1 week to control secondary bacterial infection and an antiinflammatory drug for 3 days to reduce pain and inflammation. Animal workers were also advised to clean the animals' lesions with $1 \%$ potassium permanganate solution followed by tropical application over the pock lesions with indigenous product of neem leaf extract and turmeric powder suspended in glycerin. Individual animals recovered in $\approx 1$ month. Similarly affected humans were diagnosed at primary healthcare centers and treated with oral antimicrobial drugs and analgesics for 1 week, which reduced pain and pustules. Healing was complete in 3 weeks' time. 


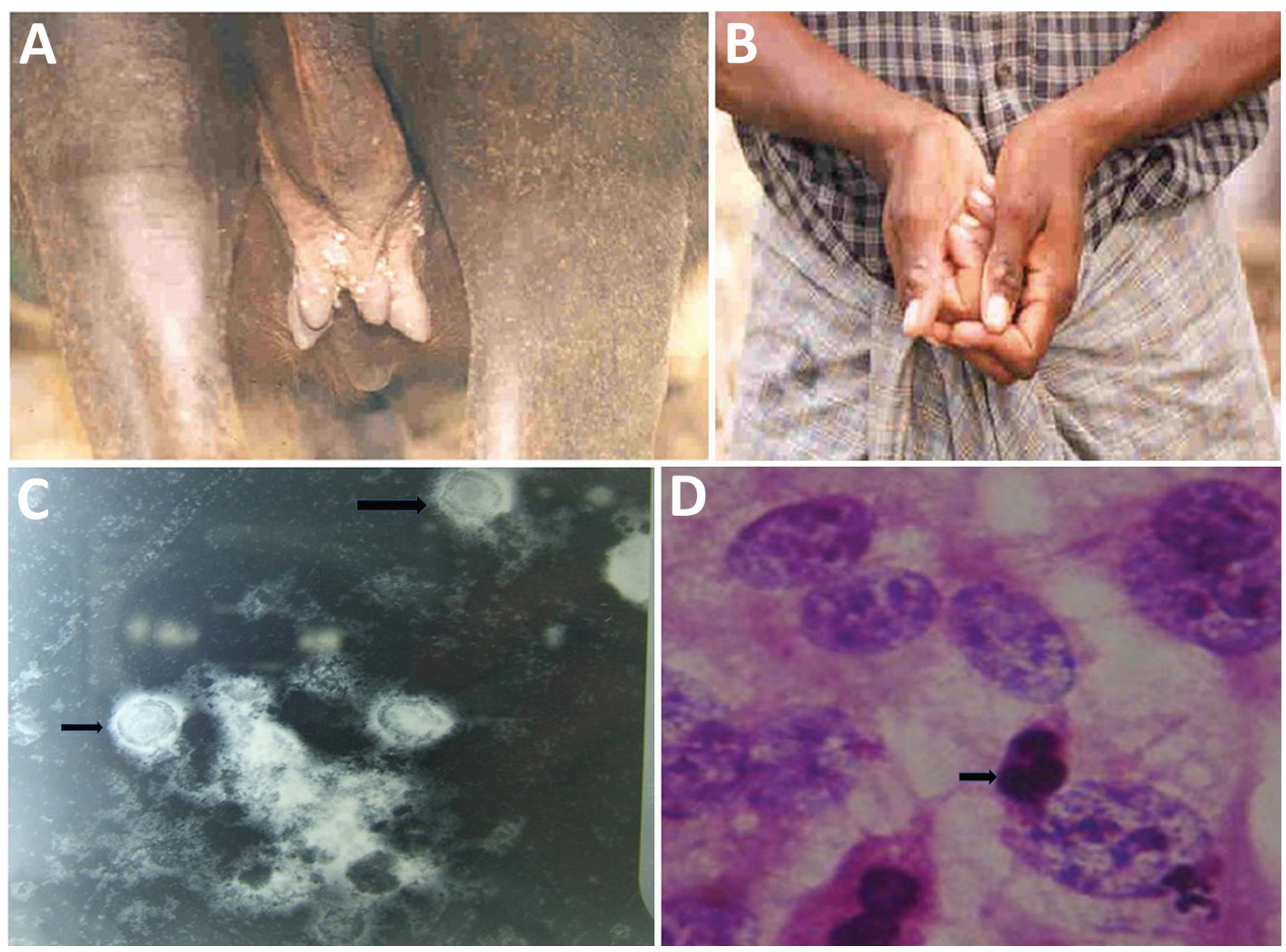

Figure. Buffalopox outbreak caused by vaccinia virus, Tamil Nadu, India. A) Buffalopox lesions on the udder and teats and over the body of a buffalo. B) Suspected buffalopox in a milker; lesions are visible on the fingers and forearms. C) Electron micrograph of vaccinia virus (arrows; magnification $\times 20,000$ ). D) Hematoxylin and eosin stain (magnification $\times 1,000$ ) shows cellular rounding and cell fusion and intracytoplasmic inclusion bodies (arrow). PCR revealed vaccinia virus infection.

The outbreaks resulted in financial loss to the farmers because of mastitis and loss of milk production. The outbreaks also created public health concern because of human infection. The source of infection could not be identified; it is possible that VACV could be lurking in rodents, as reported earlier (8), and causing sporadic outbreaks. More recently, Lima et al. reported that host range of VACV in Brazil has extended over the period 1960-2018; VACV has been detected in rodents, primates, and several species of domesticated animals as well as humans (9). Thus, continuous surveillance and the study of genetic diversity of VACV and its pathogenic attributes will be helpful to understand its founder effects and host diversity. Awareness among the stakeholders and steps taken for biosecurity will reduce the transmission of disease in animals and humans.

\section{Acknowledgments}

We thank Central Referral Laboratory, Chennai, and S. Marimuthu (DAH) and the late S. Poneerselvam for providing clinical samples and information. We thank the director of the Centre for Animal Health Studies, Tamil Nadu Veterinary and Animal Sciences University for providing necessary facilities.

\section{About the Author}

Dr. Roy is a professor in Central University Laboratory, Tamil Nadu Veterinary and Animal Sciences University, Chennai, India. His research interests are livestock and poultry disease epidemiology and zoonoses.

\section{References}

1. Dumbell K, Richardson M. Virological investigations of specimens from buffaloes affected by buffalopox in Maharashtra State, India, between 1985 and 1987. Arch Virol. 1993;128:257-67. https:// doi.org/10.1007/BF01309438 
2. Singh RK, Hosamani M, Balamurugan V, Satheesh CC, Shingal KR, Tatwarti SB, et al. An outbreak of buffalopox in buffalo (Bubalus bubalis) dairy herds in Aurangabad, India. Rev Sci Tech. 2006;25:981-7. https://doi.org/10.20506/ rst.25.3.1708

3. Gurav YK, Raut CG, Yadav PD, Tandale BV, Sivaram A, Pore MD, et al. Buffalopox outbreak in humans and animals in Western Maharashtra, India. Prev Vet Med. 2011;100:2427. https://doi.org/10.1016/j.prevetmed.2011.03.008

4. Ropp SL, Jin Q, Knight JC, Massung RF, Esposito JJ. PCR strategy for identification and differentiation of small pox and other orthopoxviruses. J Clin Microbiol. 1995;33:2069-76. https:/ / doi.org/10.1128/JCM.33.8.2069-2076.1995

5. Fenner F, Henderson DA, Arita , Jezek Z, Ladnyi ID. Smallpox and its eradication. Geneva: World Health Organization; 1988.

6. Lum GS, Soriano F, Trejos A, Llerena J. Vaccinia epidemic and epizootic in El Salvador. Am J Trop Med Hyg. 1967;16:332-8. https://doi.org/10.4269/ajtmh.1967.16.332

7. Topciu V, Luca I, Moldovan E, Stoianovici V, Plavoşin L, Milin D, et al. Transmission of vaccinia virus from vaccinated milkers to cattle. Virologie. 1976;27:279-82.

8. De Souza Lopes S, Lacerda JPG, Fonseca IEM, Castro DP, Forattini OP, Rabello EX. Cotia virus: a new agent isolated from sentinel mice in São Paulo, Brazil. Am J Trop Med Hyg. 1965;14:156-7. https://doi.org/10.4269/ajtmh.1965.14.156

9. Lima MT, Oliveira GP, Afonso JAB, Souto RJC, de Mendonça CL, Dantas AFM, et al. An update on the known host range of the Brazilian vaccinia virus: an outbreak in buffalo calves. Front Microbiol. 2019;9:3327. https://doi.org/10.3389/fmicb.2018.03327

Address for correspondence: Parimal Roy, Tamil Nadu Veterinary and Animal Sciences University, Chennai, Tamil Nadu, India; email: parimalroy580@gmail.com
An HIV-positive man from Zimbabwe living in South Africa sought treatment for multiple clinical signs, including fever, weight loss, anemia, and splenomegaly. We identified in his blood an African rodent piroplasm, $A n$ themosoma garnhami, related to Babesia species. This finding extends the known geographic and host range of A. garnhami.

A 24-year-old man from Zimbabwe who had been living in East London, South Africa, for 13 years attended a primary health care clinic in East London complaining of a 3-month period of generalized body pains, drenching night sweats, and weight loss. He had no notable previous medical history. The attending nurse diagnosed HIV infection by rapid test, collected sputum for an Xpert MTB/RIF test (Cepheid, https:/ / www.cepheid.com), and requested blood screening as preparation before initiating combination antiretroviral therapy. Malaria-like objects found on the blood smear prompted referral for specialist opinion at Cecilia Makiwane Hospital in Mdantsane, South Africa. This case report was approved by the Human Research Committee of the Faculty of Health Sciences, Walter Sisulu University, Mthatha, South Africa (protocol no. 126/2020). The patient granted written informed consent for publication of the case report.

The patient shared a house with another adult (no animals) and worked as a construction laborer. Four months before seeking treatment, he returned from a 2-month home visit to Masvingo Province in Zimbabwe. He did not recall tick bites but reported that goats and cattle lived in the village he visited.

At hospital admission, the patient was wasted (40 kg), generally weak, afebrile, and markedly pale; he had oral candidiasis. His enlarged, smooth, nontender spleen was palpable to $\approx 10 \mathrm{~cm}$ below the costal margin in the midclavicular line. No other findings were remarkable. Laboratory results (Table) showed evidence of likely hypersplenism-related pancytopenia, hemolysis, mildly raised transaminases, and advanced HIV infection. The abnormal blood smear showed intraerythrocytic parasites, initially thought to be malarial. However, concurrent rapid malaria antigen tests were negative, and the smears and whole blood sample were sent to a national parasitology reference laboratory for further assessment. On the basis of microscopic examination of Giemsa-stained blood smears (Figure), we diagnosed babesiosis accompanied by hemolytic anemia.

We started the patient on a 10-day course of oral clindamycin and quinine (each $600 \mathrm{mg}$ every $8 \mathrm{~h}$ ). Blood transfusion was not needed. After 2 weeks, all 